\title{
Behind The Camera: An Examination of Burnout and Help-seeking Among Set Workers in Turkey ${ }^{* * *}$ Kamera Arkası: Türkiye'deki Set İşçileri Arasında Tükenmişlik ve Yardım Aramanın incelenmesi
}

\begin{abstract}
Background: Set workers are employed on television, movie, and advertising production sets. Set work in Turkey has been labeled a 'hazardous occupation' (Bekçi, 2015) owing to the tremendous job demands employees face, including long hours and the lack of financial security and organizational structure. Objective: This study examined the predictors of burnout while referring to Lazarus and Folkman's (1984) concept of problem-focused coping to interpret the potential role of help-seeking in protecting against job demands. Methods: Non-random convenience sampling generated a sample of 432 participants representing a diverse range of set work experiences. Results: There were three main findings. 1. Greater job demands predicted burnout. 2. Participant background characteristics (e.g., gender, family status, children) partially predicted burnout, with gender exhibiting the greatest influence. 3. Help-seeking was minimally associated with burnout. Conclusions: We interpret the findings in the context of Turkish cultural and social dynamics that may minimize or exacerbate employee well-being and their experience of burnout.
\end{abstract}

\section{Öz}

Arkaplan: Set işçileri, televizyon, film ve reklam prodüksiyon setlerinde istihdam edilmektedir. Uzun saatler çalışmak, finansal güvence eksikliği ve organizasyonel yapı eksikliği de dahil olmak üzere, çalışanların karşılaştığı büyük iş talepleri nedeniyle Türkiye'de set işçiligi 'tehlikeli işler' sınıfına dahil edilmiştir (Bekçi, 2015). Amaç: Bu çalışma, yardım aramanın iş taleplerinden korunmadaki potansiyel rolünü yorumlamak için Lazarus ve Folkman'ın (1984) problem odaklı başa çıkma kavramına atıfta bulunarak tükenmişliğin yordayıcılarını incelemektedir. Yöntem: Rastgele olmayan kolayda örnekleme tekniği ile çeşitli iş deneyimlerini temsil eden 432 katılımcıdan oluşan bir örneklem grubu elde edilmiştir. Bulgular: Mevcut çalışmanın üç ana bulgusu vardır. 1. Büyük iş talepleri (örneğin, çalısma saatleri, günler, gelir) tükenmişliği yordamaktadır. 2. Katılımcı özellikleri (örn. cinsiyet, aile durumu, çocuklar), en büyük etkiyi gösteren cinsiyetle birlikte, tükenmişliği kısmen yordamaktadır. 3. Yardım arama, tükenmişlik ile minimal düzeyde ilişkilidir. Sonuç: Bulguları, çalışan refahını ve tükenmişlik deneyimlerini en aza indirebilecek veya şiddetlendirebilecek Türkiye kültürel ve sosyal dinamikleri bağlamında yorumluyoruz.

\section{Keywords}

Burnout, help-seeking, set work, job demands

\author{
Anahtar kelimeler \\ Tükenmişlik, yardım arama, set işçiliği, iş talepleri
}

* Istanbul Bilgi University, ece.akten@bilgi.edu.tr, ORCID: 0000-0001-8097-6190.

** Istanbul Bilgi University, ryan.wise@bilgi.edu.tr, ORCID: 0000-0002-5363-4467.

*** Akten, E. (2016). The profession without a frame: The assessment of psycho-symptomatology and help-seeking attitudes of set workers in Turkey [Unpublished master's thesis]. Istanbul Bilgi University. 


\section{Introduction}

To be a set worker in Turkey means to live a double-existence. On one hand, a set worker is a member of a production set that creates movies and television shows that millions of people across the country will watch and follow, often escaping from the economic malaise and the precariousness of their lives into the dramas of the rich and beautiful. On the other hand, set workers are similar to workers and the economically exploited than they are to the movie stars they work with; only that working conditions and the resulting challenges are hidden from plain-view as they get merged within the fantasy created and shared. The role conflict can be made very clear: Most set workers in Turkey work between 16 to 18 hours a day, 6 days a week, with no insurance, in a sector that has been classified as a "hazardous occupation" (Bekçi, 2015; Burgu, 2014; Kenarlı, 2015). And although these working conditions are often overlooked and submerged within the fantasy being created, they lead to substantial problems for workers.

\section{Background to Set Work in Turkey}

There is no single definition of a set crew, but it can be described as the group of workers who are hired by a production company to shoot a movie, television series, or advertisement. The simplest definition is that a set crew consists of the people who work behind the camera for a production. The interpretations of the job descriptions are often vague, and there are few clear distinctions between set workers employed on movie and television sets. It can be very difficult to identify clear distinctions and make a differentiation between one set worker's responsibilities and another's, as titles are often not fixed, vary between productions, and exhibit a flexibility that can lead to confusion and chaos. With production and post-production companies being simultaneously engaged in film and television productions, it can be difficult for set workers to understand where they 'belong' (Çelikcan, \& Büker, 2013).

\section{Working Conditions of Set Crews in Turkey}

There is no regulation about the working conditions of a set crew in Turkey. In most productions, the members of the set work long hours, experience unstable schedules, frequently are not paid, and navigate dangerous and unhygienic environments (Bekçi, 2015). The workers don't know when they will be done for the day as it depends on numerous factors that are impossible to calculate. Set workers are usually paid per week, but sometimes production companies are in debt and cannot pay the employees for weeks; and sometimes the workers are not paid at all (Dogan, 2015). Uncertainty penetrates into every aspect of the industry. The excessive workload and unhealthy conditions in the industry (Şeker, 2009; DHA, 2014) have led to accidents and sometimes death and suicides, which has only been exacerbated during the Covid-19 pandemic (Vardar, 2015; Öztürk, 2005; Bilge, 2009). Working long hours causes less 
sleep and exhaustion. Set members do not only deal with the external conditions but also with each other. There are many reports of insults, fights and harassment among set workers (Aral, 2016; Usanmaz, 2013, Uçar, 2013; Hararlı, 2009; Kırkeser, 2014). Since January 2015, the Cinema-Television Union has been striving to better the working conditions for set workers, although with limited success (Sinema Televizyon Sendikası, 2015). It is not surprising then, to see set work considered a "hazardous occupation" (Kenarl1, 2015).

Burnout and its Effects

Burnout is defined as the negative outcome of an individual struggling to handle a chronic source of stress (Kahill, 1988). Burnout can lead to a wide-range of negative psychological and physical results, which are partly dependent on the ability of the individual to manage their stress-related responses. Physical symptoms of burnout include fatigue, exhaustion, loss of energy, and weight loss (Eker, Anbar, \& Karabıyık, 2007). Emotional exhaustion can entail feelings of disappointment, meaninglessness, and anxiety (Kaçmaz, 2005; Lee \& Ashforth, 1990; Weinberg, Edwards, \& Garove, 1983). Emotional exhaustion can be understood as an employee's inability to focus and invest in work as a consequence of excessive psychological and emotional demands (Jackson, Schwab, \& Schuler, 1986; Dimitrios \& Konstantinos, 2014).

Burnout is also associated with depersonalization, or a distant attitude toward both work and co-workers, and encouraging a greater withdrawal from and avoidance of work-related responsibilities (Bianchi, Schonfeld, \& Laurent, 2015), and can be conceptualized as a coping mechanism through which the person attempts to distance themselves from known stressors (Jackson et al., 1986; Lee \& Ashforth, 1990). When an employee experiences burnout, they are also more likely to demonstrate lower levels of perceived personal accomplishment and consider themselves to be less capable and less effective and more incompetent (Bianchi et al., 2015). A person low in perceived personal accomplishment often exhibits less motivation and feels a sense of helplessness at work (Kaçmaz, 2005).

One of the predictors of how well an individual deals with potential sources of stress (stressors) is the degree to which they seek out help and assistance, either professional help (therapy) or social support from close others, often family members (Rickwood et al., 2005). As Uzman and Telef (2015) explain, “support from various sources can facilitate a person's problem-solving, to overcome the issues before they grow and become more serious" (p. 243). There are many barriers that often prevent people from seeking assistance, including self-stigmatization and fear of professional repercussions (Dyrbye, et al., 2021). A possible explanation for this reluctance may relate to the lack of a culture of well-being that is ignored in many professional settings, where identification with challenging work-place situations may take precedence over focusing on one's overall emotional and psychological wellness. 


\section{Help-Seeking Attitude}

Psychological help seeking is defined as an attitude of an individual which involves the tendency to seek or resist professional aid during a personal crisis or during times of psychological distress (Fischer \& Turner, 1970). Help-seeking attitudes have been found to relate with socioeconomic statuses and sex, with higher SES groups and women more likely to seek help (Özbay, Terzi, Erkan, \& Çankaya, 2011; Fischer \& Turner, 1970). Yet, research has found that in Turkey there is a general unwillingness to seek psychological help (Topkaya \& Meydan, 2013). As a collectivistic culture, the 'self' in Turkey is largely defined through important relationships and social roles (Topkaya, 2015). Friends and family are primary sources of psychological and emotional support, which often prevents individuals from seeking out mental health care when it is needed (Bilican, 2013; Setiawan, 2006).

There are several predictors of whether an individual will seek out assistance when dealing with stressors. Some of these predictors include perceived need for assistance (Shi, et al., 2020), lack of knowledge of where to seek help and limited understanding of negative mental health indicators (Gulliver, Griffiths \& Christensen, 2012), and family demographic characteristics, including gender and income (Addis \& Hoffman, 2017; Kravitz, et al., 2011). A further predictor relates to accessibility of professional assistance, both in relation to cost and availability (see below for a discussion of professional help in Turkey). One of the regularly reported predictors of help-seeking is the general approach individuals take to problem-solving and dealing with stressors, often conceptualized as problem-focused coping strategies and emotion-focused, with the former associated with greater help-seeking and lower levels of psychopathology and the latter associated with greater distress. Thomson and Jaque (2017), in a review of coping among performing artists, reported that problem-focused coping predicted not only help-seeking but was associated with a wide-variety of positive mental-health indicators. Considering that set workers are similar in many aspects to the actors and directors they support, including the reliance on creativity, moment-by-moment changes in working conditions, and a fear of failure, it seems appropriate to examine their help-seeking within this context.

\section{Theoretical Orientation--Stress and Coping Theory}

Historically, there have existed many theories attempting to explain how individuals handle stressful and difficult situations, with no one theory providing a comprehensive account of stress responses, although there have been attempts at building such a model (see, Stanislawski, 2019). In this study, we approached help-seeking behavior among set workers through the theoretical insights provided by the stress and coping theory proposed by Lazarus and Folkman (1984), one of the most influential theoretical approaches to understanding stress responses. The stress and coping theory proposes that stress occurs when the perceived deman- 
ds of a situation (stressors) outpace the personal perceived resources available to handle the situational demands. Resources may include internal resources, including emotional resources, and external, material resources. A key element in the theory is the distinction between problem-focused coping and emotion-focused coping strategies for dealing with a stressor. Problem-focused coping refers to an individual's effort to manage a stressful situation and to eliminate or modify the source of potential stress and re-establish an equilibrium between demands and resources. Emotion-focused coping involves the effort to manage one's internal responses to a stressor and regulate emotional reactions (eg., mindfulness and calming) (Folkman \& Moskowitz, 2007).

Considerable research suggests that problem-focused coping strategies are positively associated with measures of well-being, while emotion-focused coping approaches have been exhibiting a negative relationship (Braun-Lewensohn et al., 2009). In the context of occupational settings, problem-focused coping, including seeking social support, has predicted lower levels of burnout, while emotion-focused has correlated with higher levels (Shin et al., 2014). In a 2020 study of medical students, Ogoma (2020) reported that problem-focused coping led to less emotional exhaustion and greater sense of personal accomplishment. Similarly, Bamonti et al. (2019) found that certified nursing assistants using problem-focused strategies experienced less burnout than those using either dysfunctional or emotion-based coping strategies. Moreover, while there are numerous predictors of subjective well-being, studies suggest that individuals using problem-focused coping strategies exhibit generally, higher levels of well-being and lower levels of psychosocial distress than individuals relying primarily on emotion-focused strategies.

\section{Current Study and Rationale}

The aim of the current study was to address burnout within the set industry in Turkey. The first set of analyses examined the role of the workplace environment in predicting psychosocial distress among set workers. These variables included various demographic characteristics of set employees that have been previously linked to help-seeking and general well-being and burnout, including gender and age, and participants' perceptions of the job demands on the sets. Research on job-related stress suggests that although stress can be experienced by all employees, there are differences based on demographic characteristics. For example, men and women often show different stress-related symptoms, with men experiencing more health related complications (cardiovascular problems) and women more emotional problems (anxiety and depression) (Rivera-Torres, Araque-Padilla, \& Montero-Simó, 2013). Sex differences also inform to an extent the type of stressor faced. Women, for example, are more likely to experience sexual harrassment and sexual discrimination at work than are men, and the experience of sexual harrassment can lead to long-lasting effects on the person experiencing the harassment (Houle et al., 2011). Other environmental factors have also been associated with increasing 
job stress and potentially leading to negative psychological outcomes for employees (see Yang, Che, \& Spector, 2010).

In addition to both demographic characteristics associated with employees and the working environment, we focus on examining the role that individuals have in dealing with potential job-related stressors by using the transactional stress and coping theory described above (Lazarus \& Folkman, 1984). In particular, we pay attention to the role of participant help-seeking attitudes and behaviors related to obtaining psychological support services in decreasing psychosocial distress associated with job stressors and burnout. This is of particular concern in Turkey, as the therapeutic situation remains problematic. While psychological services have become more available in Turkey during the last two decades, there are still considerable problems in ensuring that people who need therapy can access it. Part of this problem is an insufficient number of trained therapists, which, when combined with the often high costs associated with therapy, has led to an undertreatment of individuals needing help. This becomes especially acute when we recall that set workers often work intermittently and are not assured a regular and stable income from their work.

Estimates indicate that a considerable percentage of the population in Turkey is dealing with a psychological disorder. The World Health Organization (WHO; 2017a) reported almost $5 \%$ of the population in Turkey was experiencing depression, although other estimates have suggested much higher figures. Additionally, according to the most recent data from the WHO there are fewer than three available psychologists per 100,000 population in Turkey, most located in urban centers (eg., Istanbul, Izmir), while the corresponding figure for Greece is 14 per 100,000, and for The Netherlands, 30 per 100,000 (WHO, 2017b). Similarly, only 1.7 psychiatrists were available per 100,000 in Turkey, which is considerably lower compared to most other countries at the same or higher economic level. Taken together, a situation emerges characterized by a highly demanding and relatively unregulated set of working conditions that has been associated with burnout, job stress, and other workplace conditions, but with relatively limited psychological support available.

Owing to the demonstrated research link between problem-focused coping strategies and various measures of mental health functioning, we predicted that workers who sought out psychological support services would exhibit less burnout and lower levels of psychosocial distress compared to those workers less focused on seeking psychological services. As described above, working on sets in Turkey is a demanding and challenging experience that has been associated with employee distress. When faced with job-related stressors, employees will respond in different ways that will affect their psychological well-being. While there are numerous ways in which employees may strive to handle a stressor, we focus primarily on seeking social support from psychological service providers and determining how this relates with various outcome measures of functioning. Seeking psychological support was conceptualized as an indicator of problem-focused coping, while psychosocial distress included measures for 
anxiety, depression, negative sense of self, somatization, hostility, emotional exhaustion, and depersonalization.

The following research questions guided the current study:

1. What is the relationship between perceived working conditions and psychosocial burnout among set workers?

2. How do participants' background characteristics (e.g., gender, income, work-place status) relate with burnout?

3. How does help-seeking attitudes and behaviors predict burnout over and beyond perceived working conditions and background characteristics of participants?

\section{Method and Materials}

\section{Participants}

Participants were selected using a non-random convenience sampling technique and were recruited through professional organizations associated with set workers. All participants responded to survey questions online, which was found to be appropriate after a consideration of the geographical distribution of set workers, the importance of generating a representative sample, and obtaining a varied set of responses from individuals across different groupings, including status, gender, sector, and age. All participants were contacted after the research obtained institutional ethics approval. There was no external funding and no conflict of interest was reported.

After data collection, three participants' data were excluded after univariate and multivariate outlier analysis. The final sample of the study consisted of 432 set workers (267 males, 165 females) who voluntarily participated in the study. Ages ranged from 18 to $58(M=30.17$, $S D=6.15)$. Twenty-two percent of the sample was married and $11.3 \%$ of the participants had children. Most of the participants $(68.5 \%$ ) had a university degree and $5.6 \%$ had a graduate degree. See below for complete demographic information for participants.

A post hoc power analysis using GPower to determine the power of the regression analysis was conducted. A baseline sample size of 400 with 7 predictor variables was used for the analyses. The recommended effect sizes were as follows: small (.02), medium (.15), and large (.35) (see Cohen, 1977). The alpha level used for all analyses in the study was $p=.05$. The post hoc analyses revealed the statistical power for this study exceeded .99 for the detection of a moderate to large effect using conventional standards for power (.80), indicating sufficient power. 
Table 1

Participant characteristics ( $N=432)$

\begin{tabular}{ccccc}
\hline Variables & M & $S D$ & $N$ & $\%$ \\
\hline Years of experience & 4.64 & 1.22 & & \\
\hline Less than 6 months & & & 12 & 2.8 \\
\hline 6 months - 1 year & & 13 & 3.0 \\
\hline $1-2$ years & & 41 & 9.5 \\
\hline 2-5 years & & 104 & 24.1 \\
\hline More than 10 years & 1.16 & 121 & 28.0 \\
\hline Type of Work & & & \\
\hline Freelance & & 360 & 83.3 \\
\hline In-house & & 72 & 16.7 \\
\hline Set Type & & & \\
\hline Movies & & 75 & 17.4 \\
\hline Television Series & & 255 & 59.0 \\
\hline Commercials & & 82 & 19.0 \\
\hline Music Clips & & 9 & 2.1 \\
\hline Catalog shootings & & 2 & .5 \\
\hline Other & & 9 & 2.1 \\
\hline
\end{tabular}

\section{Instruments}

\section{The Brief Symptom Inventory (BSI)}

The Brief Symptom Inventory (BSI) was developed by Derogatis (1975) as a shortened version of the SCL-90-R, which is a well-used, reliable, and validated measure of psychological problems and symptoms of psychopathology. The BSI was used in the current study to assess psychosocial distress among set workers. The BSI comprises 53 items which reflect 9 symptom constructs: Somatization, Obsessive-Compulsive, Interpersonal Sensitivity, Depression, Anxiety, Hostility, Phobic Anxiety, Paranoid Ideation and Psychoticism. (Derogatis \& Melisaratos 1983). Items are rated on a 5-point Likert Scale (0 not at all, $4=$ extremely) on the basis of whether the respondents experienced the symptom within the last 7 days. The BSI was adapted to Turkish and standardized by Şahin and Durak (1994) with five factors: Anxiety $(\alpha=.87)$, Depression $(\alpha=.88)$, Negative Sense of Self $(\alpha=.87)$, Somatization $(\alpha=.75)$ and Hostility $(\alpha=76)$. Based on the Turkish standardization and validation of the BSI, it was considered appropriate to use the five-factor structure in a study of set workers in Turkey. 


\section{The Scale of Attitudes toward Seeking Psychological Help - Shortened (ASPH-S)}

The ASPH-S was designed and revised by Türküm (1997) to assess attitudes toward seeking psychological help. The self-report scale consists of 18 items, rated on a 5-point Likert Scale ( 1 = strongly disagree, $5=$ strongly agree $)$ assessing participants' help-seeking in relationship to seeking out psychological support. There are two factors: 12 items for a positive attitude toward help-seeking and 6 items for a negative attitude. In its original administration, the reported internal consistency was .90 and test-retest reliability was .77. (Türküm, 2005).

\section{Maslach Burnout Inventory (MBI)}

MBI is a self-report questionnaire containing 22 items, developed by Maslach and Jackson (1981), measuring 3 dimensions of burnout: emotional exhaustion (EE), depersonalization (DP) and personal accomplishment (PA). The items are rated on a 7 point Likert Scale asking participants to indicate how often they experience each symptom $(0=$ never, $6=$ every day). Emotional exhaustion, characterized by the feelings of being drained with an excessive burden of work, was measured by 9 items; depersonalization, characterized by distant attitude toward others, was measured by 5 items and personal accomplishment, as perceived self-efficacy and capability, was measured with 8 items, and was reverse-coded in the analyses. Analysis of the reliability and validity of the MBI was done in Turkish by Ergin (1992), reducing the scale rates into 5 point Likert scales $(0=$ never, $5=$ always). Reliability coefficients were reported as: emotional exhaustion, .83; depersonalization, .71; and personal accomplishment, .72. Test retest reliability ranged from .67 to .83 . Factor analysis confirmed the 3 factor structure of the MBI in the Turkish adaptation (Öner, 2006).

\section{Results}

All scales used in the study demonstrated high reliability. Before investigating the study variables, the scores on each factor were computed and reliability coefficients were calculated. All scales and subscales had acceptable reliability coefficients ranging from .71 to .91 (See Table 2). An alpha of .05 was used for all analyses. 


\section{Table 2}

Means, Standard Deviations and Reliability Coefficients ( $\mathrm{N}=432$ )

\begin{tabular}{lccc}
\hline \multicolumn{1}{c}{ Scales / Subscales } & M & SD & $\alpha$ \\
\hline Brief Symptom Inventory & & & \\
$\quad$ Anxiety & 14.01 & 9.91 & .88 \\
\hline Depression & 18.36 & 11.37 & .91 \\
Negative Sense of Self & 14.89 & 10.26 & .90 \\
$\quad$ Somatization & 7.98 & 6.31 & .81 \\
Hostility & 10.04 & 5.83 & .80 \\
\hline Help Seeking & 36.04 & 12.72 & .90 \\
\hline Maslach Burnout Inventory & & & \\
\hline Emotional Exhaustion & 20.53 & 7.9 & .89 \\
\hline Depersonalization & 8.32 & 4.47 & .71 \\
\hline Personal Accomplishment & 20.19 & 5.05 & .72 \\
\hline
\end{tabular}

\section{Research Question 1: What is the relationship between perceived working} conditions and burnout among set workers?

Results indicated that EE was significantly and positively correlated with working days, working hours and perception of working conditions (respectively $r=.306, p<.01 ; r=.219$, $p<.01$ and $r=$ $.435, p<.01)$, whereas EE was significantly and negatively correlated with income $(r=-.139, \quad p$ $<.01)$. Indicating that participants with greater income showed less emotional exhaustion. A significant and positive correlation was found between DP and working days, working hours, and perception of working conditions $(r=.132, p<.01 ; r=.181, p<.01$; and $r=.241, p<.01)$. There was a significant and negative correlation between DP and income $(r=-.174, p<.01)$. Type of work, union membership and psychological help were not found to be statistically significant $\quad(p>.05)$.

A one-way between subjects analysis of variance (ANOVA) was used to analyze the effect of set-type on EE, DP and PA. There was a significant effect of set-type on $\mathrm{EE},(F(5,426)=$ $5.208, p<.01, d=.057)$. There was also a significant effect of set-type on DP, $(F(5,426)=3.361$, $p<.01, d=.037)$, and PA, $(F(5,426)=2.313, p<.05, d=.026)$. Post hoc analysis (Tukey HSD) revealed that only TV series and commercial workers differed significantly at $\mathrm{p}<.01$ and it was observed that set workers in TV series experienced more EE $(M=21.89, S D=7.75)$ than set workers in commercials $(M=17.65, S D=7.55)$. However, no other significant difference was found. The second post hoc test indicated that set workers in TV series experienced more DP $(M=8.87, S D=19.91)$ than set workers in commercials $(M=6.88, S D=20.38)$. Type of work, union membership and psychological help were not found to be statistically significant $(p>.05)$. 


\section{Research Question 2: How do participants' background characteristics (e.g., gender, economic status, work-place status) relate with burnout?}

A series of independent $t$ tests was conducted with gender as the grouping variable. The results indicated that gender demonstrated a significant relationship with $\mathrm{EE}(t(430)=2.777, p<.01$, $d=0.26)$, with female set workers experiencing more $\mathrm{EE}(M=21.88, S D=8.10)$ than male set workers $(M=19.70, S D=7.81)$. Gender was not statistically significant for DP and PA $(p>.05)$. The results of the second independent sample $t$ test revealed that marital status was statistically significant for DP $(t(430)=-2.198, p<.05, d=0.21)$. These results indicated that single set workers experienced more DP $(M=8.58, S D=4.57)$ than married set workers $(M=$ $7.44, S D=4.00)$. On the other hand, marital status was found to be not statistically significant for EE and PA.

The results of the analysis for child-status indicated that having children was statistically significant for the DP variable $(t(430)=-2.219, p<.05, d=0.21)$. These results indicated that set workers without children experienced more DP $(M=8.50, S D=4.50)$ than set workers with children $(M=7.00, S D=4.00)$. However, having children was not found to be statistically significant for EE and PA $(p>.05)$.

To examine set workers' economic status, separate analyses were conducted for income and insurance, an important aspect of work-place economic standing. An inspection of the correlational analysis for income indicated significant $(\mathrm{p}<.01)$ relationships with each component of burnout. Income exhibited a negative relationship with emotional exhaustion ( $r=-.14)$ and depersonalization ( $\mathrm{r}=-.17)$, indicating that workers earning less experienced greater burnout across these dimensions. Income had a positive relationship with personal accomplishment $(r=.19)$, suggesting less burnout on this component with higher incomes.

An independent $t$ test was conducted with insurance entered as the grouping variable and burnout indicators entered as dependent variables. Having insurance was statistically significant for DP $(t(430)=1.966, p<.05, d=0.18)$. Set workers with insurance experienced more DP $(M=8.58, S D=4.52)$ than set workers who didn't have insurance $(M=7.61, S D=$ 4.28). Insurance was not found to be related to EE and PA ( $p>.05)$.

An analysis of variance was used to explore the effect of set type on burnout. There was a significant effect of the set type on EE, $F(5,426)=5.208, p<.01, d=.057$. There was also a significant effect of set type on DP and PA, $F(5,426)=3.361, p<.01, d=.037$ and $F(5,426)=2.313, p<.05, d=.026$, respectively. A post hoc Tukey test revealed that only TV series and commercial workers differed significantly, with set workers in TV series having experienced more $\mathrm{EE}(M=21.89, S D=7.75)$ than those in commercials $(M=17.65, S D=$ 7.55). For DP, results indicated that TV series and commercials differed significantly in DP, with set workers in TV series experiencing more DP $(M=8.87, S D=19.91)$ than set workers in commercials $(M=6.88, S D=20.38)$. The final post hoc Tukey test revealed a significant 
difference between movies and other set types. Set workers on movies experienced more PA $(M=8.27, S D=21.28)$ than set workers in other sets $(M=6.89, S D=16.0)$. No additional significant differences were obtained.

Burnout was further examined in relation to work-place status. There was a significant effect of position on EE, $F(2,429)=7.529, p<.01, d=.187$. There was also a significant effect of position on DP and PA, $F(2,429)=8.33, p<.01, d=.197$ and $F(2,429)=10.72, p<.01$, $d=.223$, respectively. These results indicated that assistants experienced more $\mathrm{EE}(M=21.66$, $S D=8.05)$ than department heads $(M=18.81, S D=7.59)$ and also more $\mathrm{DP}(M=8.91, S D=$ 4.43) than department heads $(M=7.44, S D=4.39)$. Department heads reported higher levels of PA $(M=21.36, S D=4.99)$ than assistants $(M=19.42, S D=4.95)$.

\section{Research Question 3: How does help-seeking attitudes and behaviors predi- ct burnout over and beyond perceived working conditions and background characteristics of participants}

Correlations were computed among the three subscales of burn-out: emotional exhaustion (EE), depersonalization (DP), and personal accomplishment (PA) (See Table 3). An inspection of the intercorrelations (See Table 3) showed that emotional exhaustion was not significantly correlated with help-seeking $(p>.05)$. Depersonalization exhibited a positive correlation with help-seeking $(r=.097, p<.05)$ and personal accomplishment and a negative relationship $(r=$ $-.101, p<.05)$. These results indicate that depersonalization was lower among those participants seeking psychological help, and sense of personal accomplishment was higher. However, an inspection of the correlations indicates that these last two relationships, while significant, are weak, suggesting the possibility of a statistical artifact or a small effect size.

\section{Table 3}

Correlations between Symptoms, Burnout, and Help-Seeking

\begin{tabular}{lccc}
\hline & $\begin{array}{c}\text { Emotional } \\
\text { Exhaustion }\end{array}$ & Depersonalization & $\begin{array}{c}\text { Personal } \\
\text { Accomplishment }\end{array}$ \\
\hline Anxiety & $.479 * *$ & $.503 * *$ & $-.113^{*}$ \\
\hline Depression & $.453^{* *}$ & $.444^{* *}$ & -.089 \\
\hline Negative Sense of Self & $.450 * *$ & $.522^{* *}$ & -.077 \\
\hline Somatization & $.336^{* *}$ & $.336^{* *}$ & -.076 \\
\hline Hostility & $.410^{* *}$ & $.471 * *$ & -.088 \\
\hline Help Seeking & 027 & $.097 *$ & $-.101 *$ \\
\hline $\begin{array}{l}\text { Note: Correlations marked with two asterisk }(* *) \text { were significant at } p<.01, \text { correlations marked with an asterisk } \\
(*) \text { were significant at } p<.05 .\end{array}$ & & \\
& & \\
\end{tabular}


Results of the analysis indicated that the entering of background information in the first step of the regression analysis and distress in the second step explained a significant amount of variance in the $\mathrm{EE}$ (respectively, $\mathrm{F}(7,424)=19.975, \mathrm{p}<.01, \mathrm{R} 2=.25$, R2 Adjusted =.24, R2 Change $=.248$ and $\mathrm{F}(12,419)=23.386, \mathrm{p}<.01, \mathrm{R} 2=.40, \mathrm{R} 2$ Adjusted $=.38$, R2 Change $=.153)$. An analysis of the regression model and the predictors indicated that working days $(\beta=.19$, $\mathrm{t}=4.03, \mathrm{p}=.00)$ and working conditions $(\beta=.34, \mathrm{t}=7.17, \mathrm{p}=.00)$ were significant in Step 1. In Step 2 , gender $(\beta=-.08, t=-2.03, p=.04$. $)$ and anxiety $(\beta=.39, t=4.38, p=.00)$ predicted $E E$.

A second regression analysis was conducted to determine the relationship between background characteristics, psychosocial distress, and help-seeking attitudes and DP. The results indicated that these variables explained a significant amount of variance in the DP (respectively, $F(10,420)=6.075, p<.01, \mathrm{R}^{2}=.13, \mathrm{R} 2$ Adjusted $=.11, \mathrm{R}^{2}$ Change $=.126$ and $F(16,414)=$ $14.062, p<.01, \mathrm{R}^{2}=.35, \mathrm{R} 2$ Adjusted $=.33, \mathrm{R}^{2}$ Change $\left.=.226\right)$. Negative sense of self $(\beta=.32, \mathrm{t}=$ $3.51, \mathrm{p}=.00)$ and somatization $(\beta=-.15, \mathrm{t}=-2.32, \mathrm{p}=.02)$ were significant predictors.

The final multiple regression analysis examined whether background information, distress and help-seeking predicted PA. The results of the analysis showed that these variables explained a significant amount of variance in PA (respectively, $\mathrm{F}(6,424)=7.422$, $\mathrm{p}<.01$, $\mathrm{R}^{2}=.09, \mathrm{R} 2$ Adjusted $=.08, \mathrm{R}^{2}$ Change $=.095$ and $\mathrm{F}(8,422)=6.095, \mathrm{p}<.01, \mathrm{R}^{2}=.10, \mathrm{R} 2$ Adjusted $=.09, \mathrm{R}^{2}$ Change $\left.=.009\right)$. Perception of working conditions $(\beta=-.20, t=-4.21, p=.00)$ and income $(\beta=.12, t=2.00, p=.047)$ were found to be significant predictors in Step 1. In Step 2 , only perception of working conditions $(\beta=-.20, \mathrm{t}=-4.16, \mathrm{p}=.00)$ was a significant predictor.

\section{Discussion}

The primary objective of this study was to contribute to the understanding of burnout in relation to help-seeking attitudes of set workers in Turkey. The major aim was to draw attention to this "frameless profession" and its relation to the psychological well-being of its employees and the challenges they face. Our analysis first examined burnout as a function of workplace environment and conditions, while then moving to an examination of our main research predictions.

Research question one explored the relationship between perceived working conditions and burnout, as measured by emotional exhaustion, depersonalization, and perceptions of personal accomplishment. Our results indicated that when set workers worked on sets more days in a week and more hours in a day burnout increased. This finding was consistent with the findings of Ray (1991), as unrealistic and challenging expectations can lead to employee overload and feelings of isolation (see also, Lewandowski, 2015). Studies in Turkey reveal that work overload and longer working hours could be considered as one of the major factors contributing to burnout (Alimoglu, \& Dönmez, 2005; Oguzberk, \& Aydın, 2008; Günüsen, \& Üstün, 2010). Emotional burden, tension, mental fatigue, as well as a distant attitude toward others, less motivation and withdrawal, all accompany work overload. Another important factor in burnout is earned income. 
According to our results, when set workers earned more per week, emotional exhaustion and depersonalization decreased. We interpret this finding as reflecting that workers earning more may feel that they are being accurately recognized for their contributions and valued more. This finding is in line with previous research showing a negative correlation between income and burnout (Dubale et al., 2019). We further interpret this outcome as suggesting that at higher income levels, participants are better able to afford and access psychological support. Considering that therapy is not a one-time event, but is a process that can last months or years, having a regular salary, something not common among set workers, and a relatively high income would predict not only access to therapy but continued attendance. However, it is important to note that while analysis of earned income was possible, the distribution of income was limited to the middle ranges, as very few or no employees earned at the very bottom or at the very top of the income range provided for participants.

The results indicated that gender was a significant predictor for emotional exhaustion, but not for depersonalization and personal accomplishment. It was found that female set workers experienced more emotional exhaustion than did male set workers, which can be related to previous studies having found that female employees engage in more emotional care and take on a greater emotional burden than male employees (Dikmetas, Top, \& Ergin, 2011; Schweitzer, 1994). The gendering of emotional labor is not new (see Hothschild, 1979, 1983), yet when investigating a new sector, it is important to highlight similarities with findings from different sectors and different environments. One limitation here, and a topic that deserves more attention in job sectors similar in characteristics to set work (i.e., intermittent employment, high job demands, and an unstructured labor setting) is the type of emotional work and burdens faced by women.

Although Eker et al. (2007) found no relation between marital status, having children, and burnout, the present study revealed that, when marital status was taken into consideration, single set workers had higher depersonalization than married ones. Marital status and having children were not found to be significant for emotional exhaustion and personal accomplishment. Being single and not having children were also found to be related to burnout and lower personal accomplishment (Toker, 2011; Günüşen, \& Üstün, 2010). Having a family could be thought of as a protective factor, as social support has been reported to help prevent burnout (Hobfoll \& Freedy, 1993; Topkaya, 2015). While this study focused on seeking professional help, many people who seek assistance do so from family members and close loved-ones, thus helping to explain why not married participants reported lower levels of personal accomplishment. It is unclear why there was no predictive relationship between marital status and having children and the other measures of burnout. One possible explanation, though, is that owing to the unstable work schedules, lack of a predictable income, and travel required for shooting television shows and movies, individuals wishing to have a family are less likely to work on a set. This finds confirmation in our study, as only $22 \%$ of the set workers were married, and $11 \%$ had children, suggesting that there is a selection bias present when examining the backgrounds of set workers in Turkey. 
Set workers for television series' sets experienced more burnout than those working in advertisement sets. Television work in Turkey exacts a high demand on workers, as television shows are filmed in a relatively short time, but owing to the number of episodes produced, require long hours and limited breaks in-between shoots. Set workers working in movie sets displayed higher levels of personal accomplishment than the others. Television series' sets were perceived as the most difficult set by the workers, in terms of workload, with job status predicting burnout. This finding was also consistent with the findings of Toker (2011) and Eker et al. (2007).

Findings suggested a positive correlation between emotional exhaustion and depersonalization with depression and anxiety. While no relation between personal accomplishment was found, there was a negative relationship with anxiety. Tunçel et al., (2014) also found out that there was a strong relationship between depression, anxiety and EE whereas there was a weaker, although significant, relationship between depression and DP. A study which investigated the association between burnout and depression also revealed that EE had the strongest correlation with depression among other subscales (Bakir et al., 2010). Burnout was found to be moderately but significantly correlated with depression and anxiety (Toker, Shirom, Shapira, Berliner, \& Melamed, 2005).

The third research question examined help-seeking and its relation with psychosocial distress. Seeking psychological help can be conceptualized as a form of problem-focused coping in relation to job demands and job stressors. As discussed above, problem-focused coping has been generally associated with measures of psychological well-being (Mayordomo et al., 2015). Thus we predicted that beyond the variability accounted for by background characteristics of participants (i.e., working conditions and gender), psychological help-seeking would explain additional variability in burnout. While there was not an attempt to compare outcomes for participants' use of problem-focused and emotion-focused coping, a possible limitation, in the context of the therapeutic situation in Turkey (see above), we thought it germane to limit our analysis to an examination of seeking psychological help.

Bilican (2013) argued that there had been a gap between treatment needs and meeting those needs. In the present study, it was found that there was a significant positive relation between DP and attitude toward seeking psychological help. As depersonalization is characterized with a distant attitude toward others, the results of the present study were consistent with Topkaya (2015), who found that public stigma was related to lower levels of help-seeking. There was also a negative association between personal accomplishment and help-seeking. However there was no relation between emotional exhaustion and help-seeking. Further, attitude toward seeking psychological help was not a predictor of burnout over and beyond what was accounted for by the other predictor variables. This was an interesting finding, and did not support our prediction that help-seeking would predict burnout levels.

There could be several explanations for this finding between help-seeking and burnout levels. First, we measured help-seeking in the context of psychological help. Individuals from collectivist cultures have been reported to solve their problems on their own or seek help from 
their families rather than from professionals (Bilican, 2013; Mocan-Aydın, 2000). According to Hofstede Insights (2021), which provides global rankings on different dimensions of cultural dynamics, Turkey scores at $37 \%$ on measures of individualism, indicating that it is a relatively collectivist culture, indicating that social support is often located in the family, both immediate and extended. Thus, set worker participants in our study experiencing burnout may have found and received support from family members and were less likely to seek psychological help, explaining the non-significant findings reported. Willingness to seek psychological help has also been reported as a hindrance to reaching out for professional assistance, and may also partly explain why the participants in the current study may have turned to family support rather than psychological professionals (Çiftçi, Jones, \& Corrigan, 2013; Topkaya, 2015). Possibly also, participants were not aware of how therapy and related services could help ameliorate their experience of burnout at an individual level, and as previously discussed, one of the barriers to seeking psychological help is a lack of knowledge concerning the psychological nature of experiences of distress and ill-being.

\section{Contributions of the Current Study}

We identify two major contributions of the current study. First, and foremost, this is one of the few empirical research studies that sheds light on the working conditions of employees engaged in the production of television shows, movies, and commercials. As stated at the outset, this sector is relatively overlooked, often dangerous, and lacking in structural clarity. With limited regulation and an unstable working environment, set workers are at a much greater likelihood of experiencing excessive job demands, precarity, and instability, and when combined with a lack of resources, these can lead to serious burnout, stress, anxiety, depression, and lowered self-esteem. Thus, like any work environment that poses substantial risk to employees, it is important that researchers focus their attention on those sectors that may go unrecognized and be provided less attention.

The second contribution of our research findings relates to the way in which help-seeking contributed to an understanding of psychosocial distress. As conceptualized in this study, help-seeking was analyzed by examining participants' attitudes and behaviors toward accessing and seeking psychological support services. According to the stress and coping model developed by Lazarus and Folkman (1984), individuals when confronted with stressors respond in both behavioral and cognitive ways to minimize the effects of stressors and to maintain an equilibrium between self and environmental demands. Researchers working within this framework have frequently distinguished between problem-focused coping styles and emotion-focused coping styles. Although the research is conflicting in regards to classification of coping behaviors and thought processes, one finding that has been supported is that problem-focused strategies are associated with better outcomes, including higher self-esteem and resiliency (Vaughn \& Roesch, 2003). 
The results reported in this study are mixed, and should be interpreted as providing limited support for the prediction that help-seeking behaviors would mitigate burnout among set workers. While help-seeking behaviors exhibiting a significant relationship with depersonalization (positive) and personal accomplishment (negative), there was no relationship with emotional exhaustion. When we entered the predictor variables into multiple regression analysis examining the psychosocial distress outcome variables, help-seeking did not contribute toward explaining a significant amount of the variability. This suggests that when trying to understand burnout among set workers, it may be of greater importance to focus on the structural components of the job setting. In each of the regression analyses, participants' perception of the working conditions was a consistent significant predictor of each outcome measure: depersonalization, emotional exhaustion, and personal accomplishment.

\section{Limitations and Implications for Future Research}

The main limitation of the study was the sample characteristics. The participation was voluntary and the participants were recruited by a non-random convenience sampling technique. While some characteristics of the sample might make it difficult to generalize the findings, the numerical size of the sample (432) was big enough to allow for tentative conclusions.

This is one of the first studies of set workers in Turkey, a sector that is hidden from

view and working without a clear frame and boundary relating to working conditions, expectations, and avenues for addressing well-being. It is almost a shadow industry that is ignored as the television and movie stars receive adulation and huge salaries, and it is uncritically assumed that all workers must receive and experience the same glamorous life-style. We suggest that future studies attend to on-set harassment and discrimination as this was not able to be fully addressed in the current study. Further, examining how set workers access help services would provide a greater context to understanding their well-being and may provide therapists and others routes to provide psychological assistance.

\section{References}

Addis, M. E., \& Hoffman, E. (2017). Men's depression and help-seeking through the lenses of gender. In R. F. Levant \& Y. J. Wong (Eds.), The psychology of men and masculinities (pp. 171-196). American Psychological Association. https://doi.org/10.1037/0000023-007

Alimoğlu, M.K., \& Dönmez, L. (2005). Daylight exposure and the other predictors of burnout among nurses in a university hospital. International Journal of Nursing Studies, 42, 549-555.

Aral, A. (2016). Tardu Flordun hakkındaki o iddalar doğru çıktı. Hürriyet. Retrieved from http://www. hurriyet.com.tr/. 
Bakir, B., Ozer, M., Ozcan, C.T., Cetin, M., \& Fedai, T. (2010). The association between burnout and depressive symptoms in a Turkish military nurse sample. Bulletin of Clinical Psychopharmacology, 20(2), 160-163.

Bamonti, P., Conti, E., Cavanagh, C., Gerolimatos, L., Gregg, J., Goulet, C., Pifer, M., \& Edelstein, B. (2019). Coping, Cognitive Emotion Regulation, and Burnout in Long-Term Care Nursing Staff: A Preliminary Study. Journal of Applied Gerontology, 38(1), 92-111. https://doi.org/10.1177/0733464817716970

Bekçi, E. (2015). 'Setlerdeki çalışma koşulları insanlık sınırlarını zorlayan düzeyde'. Haber Sol. Retrieved from http://haber.sol.org.tr.

Bianchi, R., Schonfeld, I.S., \& Laurent, E. (2015). Is it time to consider "burnout syndrome" a distinct illness?. Frontiers in Public Health, 3(158). doi: 10.3389/fpubh.2015.00158

Bilican, F.I. (2013). Help-seeking attitudes and behaviors regarding mental health among Turkish college students. International Journal of Mental Health,42(2-3), 43-59.

Bilge, B. (2009). Cem Yılmaz’ın film setinde esrarengiz ölüm. Vatan. Retrieved from http://www.gazetevatan. com.

Braun-Lewensohn O, Celestin-Westreich S, Celestin L-P, Verleye G, Verte D, \& Poncaert-Kristoffersen I. 2009). Coping styles moderating the relationships between terrorist attacks and well-being outcomes. J Adolescence, 32 (3): 585-599.

Burgu, S. (2014, September 14). 10 dakika fazla uykuyu düşleyenler: Set çalışanları. Haber Sol. Retrieved from http://haber.sol.org.tr

Cohen, J. (1977). Statistical Power Analysis for the Behavioral Sciences (revised Edn.). Academic Press.

Çelikcan, P. \& Büker, N. (2013). Televizyon Yayıncılı̆̆ı ve Yapımcılı̆̆ı Meslek Haritalama Raporu.

Çiftçi, A., Jones, N., \& Corrigan, P.W. (2013). Mental health stigma in the Muslim community. Journal of Muslim Mental Health, 7(1), 17-32.

Derogatis, L.R., \& Melisaratos, N. (1983). The brief symptom inventory: An introductory report. Psychological Medicine, 13, 595-605.

DHA. (2014). Reklam setinde can pazarı. Milliyet. Retrieved from www.milliyet.com.tr.

Dikmetaş, E., Top, M., \& Ergin, G. (2011). Asistan hekimlerin tükenmişlik ve mobbing düzeylerinin incelenmesi. Türk Psikiyatri Dergisi, 22(3), 137-149.

Dimitrios, B., \& Konstantinos, V. (2014). “Organizational culture and job burnout- a review”. International Journal of Research in Business Management, 2(1), 43-62.

Doğan, M. (2015). Dizi emekçileri ne kadar kazanıyor? Haber Türk. Retrieved from http://www.haberturk. com.

Dyrbye, L. N., Leep Hunderfund, A. N., Winters, R. C., Moeschler, S. M., Vaa Stelling, B. E., Dozois, E. J., Satele, D. V., \& West, C. P. (2021). The Relationship Between Burnout and Help-Seeking Behaviors, Concerns, and Attitudes of Residents. Academic medicine: journal of the Association of American Medical Colleges, 96(5), 701-708. https://doi.org/10.1097/ACM.0000000000003790

Dubale, B.W., Friedman, L.E., Chemali, Z. et al. (2019). Systematic review of burnout among healthcare providers in sub-Saharan Africa. BMC Public Health 19, 1247. https://doi.org/10.1186/s12889-019- 
Eker, M. Anbar, A., \& Karabiyık, L. (2007). The relationship between demographic characteristics and burnout among academicians in Turkey. Akademik Araştırmalar Dergisi, 34, 14-35.

Ergin, C. (1992). Doktor ve hemşirelerde tükenmişlik ve Maslach tükenmişlik envanterinin uygulanması. 7. Ulusal Psikoloji Kongresi Bilimsel Çalısmaları, 143-154.

Fischer, E.H., \& Turner, J.L. (1970). Development and research utility of an attitude scale. Journal of Consulting and Clinical Psychology, 35(1), 79-90.

Folkman, S., \& Moskowitz, J. T. (2007). Positive affect and meaning-focused coping during significant psychological stress. In M. Hewstone, H. A. W. Schut, J. B. F. De Wit, K. Van Den Bos, \& M. S. Stroebe (Eds.), The scope of social psychology: Theory and applications (pp. 193-208). Psychology Press.

Gulliver, A., Griffiths, K.M. \& Christensen, H. (2012). Barriers and facilitators to mental health help-seeking for young elite athletes: a qualitative study. BMC Psychiatry 12, 157. https://doi.org/10.1186/1471244X-12-157

Günüşen, N.P., \& Üstün, B. (2010). Türkiye'de ikinci basamak sağlık hizmetlerinde çalışan hemşire ve hekimlerde tükenmişlik: Literatür incelemesi. DEUHYO ED, 3(1), 40-51.

Hararlı, D. (2009). TRT setinde taciz iddiası. Hürriyet. Retrieved from http://www.hurriyet.com.tr/.

Hobfoll, S. E., and Freedy, J. (1993). Conservation of resources: A general stress theory applied to burnout. In W. B. Schaufeli, C. Maslach and T. Marek (Eds.), Professional burnout: Recent developments in theory and practice (pp. 115-133). Taylor and Francis.

Hochschild, A. R. (1979). Emotion work, feeling rules, and social structure. American Journal of Sociology, 85(3), 551-575. doi:10.1086/227049

Hochschild, A. R. (1983). The managed heart: Commercialization of human feeling. Berkeley, CA: University of California Press.

Hofstede Insights. (August 29, 2001). Retrieved from: https://www.hofstede-insights.com/country/turkey/

Houle, J. N., Staff, J., Mortimer, J. T., Uggen, C., \& Blackstone, A. (2011). the impact of sexual harassment on depressive symptoms durıng the early occupational career. Society and mental health, 1(2), 89-105.

Jackson, S.E., Schwab, R.L., \& Schuler, R.S. (1986). Toward an understanding of the burnout phenomenon. Journal of Applied Psychology, 71(4), 630-640.

Kaçmaz, N. (2005). Tükenmişlik (burnout) sendromu. Journal of Istanbul Faculty of Medicine, 68, 29-32.

Kahill, S. (1988). Symptoms of professional burnout: A review of the empirical evidence. Canadian Psychology, 29(3), 284-297.

Kenarlı, G. (2015). Setler artık 'tehlike' sınıfında. Radikal. Retrieved from http://www.radikal.com.tr

Kırkeser, S. (2014). Recep İvedik 4 setinde dayak. Hürriyet. Retrieved from http://www.hurriyet.com.tr/.

Kravitz RL, Paterniti DA, Epstein RM, Rochlen AB, Bell RA, Cipri C, et al. Relational barriers to depression help-seeking in primary care. Patient Educ Couns (2011) 82:207-13. doi: 10.1016/j.pec.2010.05.007

Lazarus R.S., \& Folkman S. (1984). Stress, appraisal, and coping. New York: Springer.

Lee, R., \& Ashforth, B. (1990). On the meaning of Maslach's three dimensions of burnout. Journal of Applied Psychology, 75, 743-747.

Lewandowski, C.A. (2015). Organizational factors contributing to worker frustration: The precursor to burnout. The Journal of Sociology \& Social Welfare, 30(4), 175-185. 
Maslach, C., \& Jackson, S.E. (1981). The measurement of experienced burnout. Journal of Occupational Behaviour, 2, 99-113.

Mayordomo, T., Viguer, P., Sales, A., Satorres, E., \& Meléndez, J. C. (2016). Resilience and coping as predictors of well-being in adults. The Journal of Psychology, 150(7), 809-821. DOI: 10.1080/00223980.2016.1203276

Mocan-Aydın, G. (2000). Western models of counseling and psychotherapy within turkey: Crossing cultural boundaries. The Counseling Psychologist, 37(2), 281-298.

Ogoma, S. O. (2020). Problem-focused coping controls burnout in medical students: The case of a selected medical school in Kenya. Journal of Psychology, 8(1), 69-79.

Oğuzberk, M., \& Aydın, A. (2008). Ruh sağlığı çalışanlarında tükenmişlik. Klinik Psikiyatri, 11, 167-179.

Öner, N. (2006). Türkiye’de Kullamlan Psikolojik Testlerden Örnekler Bir Başvuru Kaynağı. BÜTEK.

Özbay, Y., Terzi, Ş., Erkan, S., \& Çankaya, Z.C. (2011). Üniversite öğrencilerinin profesyonel yardım arama tutumları, cinsiyet roller ve kendini saklama düzeyleri. Pegem Eğitim ve Öğretim Dergisi, 1(4), 59-71.

Öztürk, A. (2005). Dizi setinde korkunç kaza. Haber Vitrini. Retrieved from http://www.habervitrini.com.

Ray, E. (1991). The relationship among communication network roles, job stress and burnout in educational organizations. Communication Quarterly, 39, 91-102.

Rickwood, D., Deane F.P, Wilson, C.J., \& Ciarrochi, J. (2005). Young people's help seeking for mental health problems. Aust e-J Advancement Mental Health, 4, 1-34.

Rivera-Torres, P., Araque-Padilla, R. A., \& Montero-Simó, M. J. (2013). Job stress across gender: the importance of emotional and intellectual demands and social support in women. International journal of environmental research and public health, 10(1), 375-389. https://doi.org/10.3390/ijerph10010375

Schweitzer, B. (1994). Stress and burnout in junior doctors. S Afr Med J, 84, 352-354.

Setiawan, J.L. (2006). Willingness to seek counselling and factors that facilitate and inhibit the seeking of counselling in Indonesian undergraduate students. British Journal of Guidance \& Counselling, 34(3), 403-419.

Shi, W., Shen, Z., Wang, S., \& Hall, B. J. (2020). Barriers to Professional Mental Health Help-Seeking Among Chinese Adults: A Systematic Review. Frontiers in psychiatry, 11, 442. https://doi.org/10.3389/ fpsyt.2020.00442

Shin, H., Park, Y. M., Ying, J. Y., Kim, B., Noh, H., \& Lee, S. M. (2014). Relationships between coping strategies and burnout symptoms: A meta-analytic approach. Professional Psychology: Research and Practice, 45(1), 44-56. https://doi.org/10.1037/a0035220

Sinema Televizyon Sendikası. (2015). Retrieved from http://www.sinematvsendikasi.org .

Stanisławski K. (2019). The Coping Circumplex Model: An Integrative Model of the Structure of Coping With Stress. Frontiers in psychology, 10, 694. https://doi.org/10.3389/fpsyg.2019.00694

Şahin, N.H., \& Durak, A. (1994). Kısa semptom envanteri: Türk gençleri için uyarlaması. Türk Psikoloji Dergisi, 9(31), 44-56.

Şeker, B. (2009). Set kazaları ve zihniyet problemleri. Bianet. Retrieved from http://bianet.org/.

Thomson, P., and Jaque, V. S. (2017). Creativity and the Performing Artist: Behind the Mask. Elsevier Press.

Toker, B. (2011). Burnout among university academicians: An empirical study on the universities of Turkey. Doğuş Üniversitesi Dergisi, 12(1), 114-127. 
Toker, S., Shirom, A., Shapira, I., Berliner, S., \& Melamed, S. (2005). The association between burnout, depression, anxiety and inflammation biomarkers: C-reactive protein and fibrinogen in men and women. Journal of Occupational Health Psychology, 10(4), 344-362.

Topkaya, N. (2015).Willingness to seek psychological help among Turkish adults. Revista de cercetare si intervintie sociala, 48, 149-163.

Topkaya, N., \& Meydan, B. (2013). Üniversite öğrencilerinin problem alanları, yardım kaynakları ve psikolojik yardım alma niyetleri. Trakya Üniversitesi Eğitim Fakültesi Dergisi, 3(1), 25-37.

Tunçel, Y.İ., Kaya, M., Kuru, R.N., Menteş, S., \& Ünver, S. (2014). Nurses’ burnout in oncology hospital critical care unit. Türk Yoğun Bakım Derneği Dergisi, 12, 57-62.

Türküm, A.S. (2005). Who seeks help? Examining the differences in attitude of Turkish university students toward seeking psychological help by gender, gender roles and help-seeking experiences. The Journal of Men's Studies, 13(3), 389-401.

Uçar, B.P. (2013). Ünlü oyuncuya 380 gün hapis. Hürriyet. Retrieved from http://www.hurriyet.com.tr/.

Uzman, E., \& Telef, B. B. (2015). Prospective teachers' mental health and their help-seeking behaviours. Düsünen Adam: Journal of Psychiatry and Neurological Sciences, 28(3), 242-254.

Usanmaz, G. (2013). Kulağını patlattığı kameraman affetmedi. Habertürk. Retrieved from http://www. haberturk.com/.

Vardar, N. (2015). Selin Erdem'in öldüğü tehlikeli set AİHM'de. Bianet. Retrieved from http://bianet.org.

Vaughn A.A. \& Roesch, S. C. (2003). Psychological and physical health correlates of coping in minority adolescents. Journal of Health Psychology 8(6):671-683.

Weinberg, S., Edwards, G., \& Garove, W.E. (1983). Burn-out among employees of state residential facilities serving developmentally disabled persons. Children and Youth Services, 5(3), 239-253.

World Health Organization (2017a). Depression and Other Common Mental Disorders: Global Health Estimates. World Health Organization.

World Health Organization (2017b). Mental Health Atlas--Turkey. World Health Organization.

Yang, L.-Q., Che, H. and Spector, P.E. (2008), Job stress and well-being: An examination from the view of person-environment fit. Journal of Occupational and Organizational Psychology, 81: 567-587. https:// doi.org/10.1348/096317907X243324 
